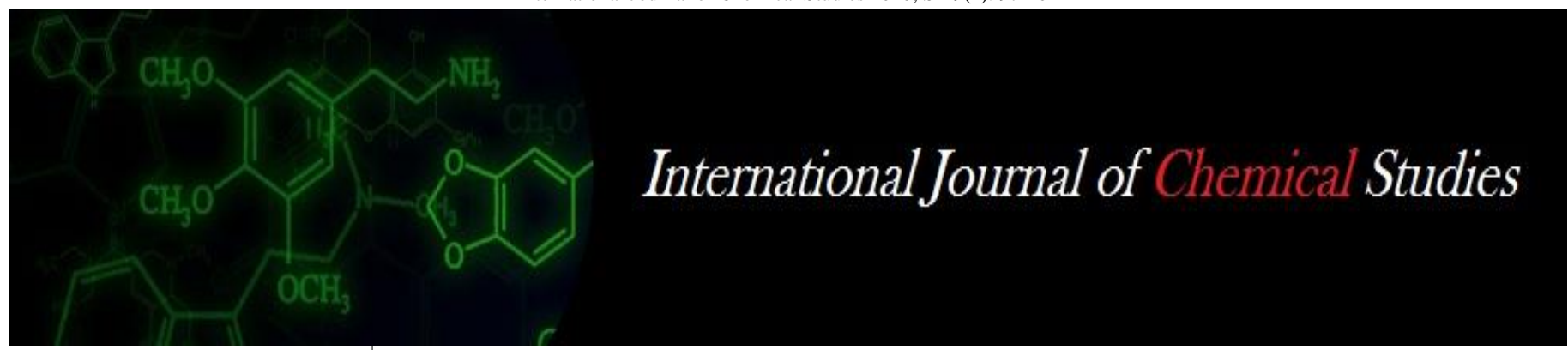

P-ISSN: 2349-8528

E-ISSN: 2321-4902

www.chemijournal.com

IJCS 2021; SP-9(1): 97-101

(C) 2021 IJCS

Received: 17-11-2020

Accepted: 23-12-2020

DP Singh

Senior Scientist and Head, Krishi

Vigyan Kendra, ANDUAT,

Basuli, Maharajganj, Uttar

Pradesh, India

V Chandra

Associate Professor/SMS, AS,

Krishi Vigyan Kendra,

ANDUAT, Basuli, Maharajganj,

Uttar Pradesh, India

T Tiwari

Programme Assistant, Krishi

Vigyan Kendra, ANDUAT,

Basuli, Maharajganj, Uttar

Pradesh, India
Corresponding Author: DP Singh

Senior Scientist and Head, Krishi

Vigyan Kendra, ANDUAT,

Basuli, Maharajganj, Uttar

Pradesh, India

\section{Evaluation of different Kalanamak rice genotypes for yield and yield related traits of eastern Uttar Pradesh}

\author{
DP Singh, V Chandra and T Tiwari
}

DOI: https://doi.org/10.22271/chemi.2021.v9.i1b.11449

\begin{abstract}
Crop genotypes play a dominant role in crop production systems. Uttar Pradesh has been the home of some of the finest quality scented rices. Kalanamak is an important and popular scented rice variety grown in Eastern Uttar Pradesh. This variety is famous for its taste and aroma. In eastern India it is cooked in honour of guest or given as gift. It can be boon for farmers of Eastern Uttar Pradesh and Tarai area of Bihar. In present study $7+2$ lines/varieties of Kalanamak, collected from IARI, New Delhi were evaluated on the basis of vital to know the effects of various characters on yield for selection criteria for high yielding genotype. The experiments laid out of two set $1^{\text {st }}$ was on station and $2^{\text {nd }}$ on farmers field of Maharajganj district with two block and two villages viz: block Siswa Bazar (Gopala \& Keshrari), Meethura (Karuta \& Parsauni). Yield and yield related traits were studied. Statistical analysis exhibited that rice varieties differed significantly for days to $50 \%$ flowering, plant height $\mathrm{cm}$, panicle per sqm, no. of spikelet's/panicle, SRF\% grain yield $\mathrm{kg} / \mathrm{ha}$, grain type and insect/pest and disease. Moreover, significantly positive genotypic correlations of grain yield with plant height and panicle/m2 were observed. Principal component analysis also classified superior varieties, shows that maximum yield was recorded for station trial and farmers field the genotypes of Pusa 1652-10-11-2-1-1-1 on station and farmers field grain yield of (3134 kg/ha \& $3096 \mathrm{~kg} / \mathrm{ha}), \%$ increase over check Bouna Kalanamak on station and farmers field $18.4 \%$ \& $19.39 \%$, followed by Pusa 07-62-3-13 grain yield of on station and farmers field ( $3059 \mathrm{~kg} / \mathrm{ha} \& 3088 \mathrm{~kg} / \mathrm{ha}$ ), grain yield increase over check was on station and farmers field $15.21 \%$ and $18.78 \%$ have high yield stability. The investment on production by adopting improved Kalanamak line/varieties with a value of Rs. 32192/ha. Cultivation of under improved Kalanamak line/varities Pusa 1652-10-11-2-1-1-1fetch higher net return of value Rs. 95,976/- compared to check variety Bouna Kalanamak to amount of Rs. 80,383/- ha, followed by Pusa 07-62-3-13 Rs. 95,480/-, Pusa 1638-07-130-2-67-1-1-1 Rs. 92,504/- and Pusa 1652-10-11-2-2-2-3 of Rs. 90,613/-. The B:C ratio of improved Kalanamak lines/varieties of Pusa 1652-10-11-2-1-1-1was 2.98, followed by Pusa 07-62-3-13 was 2.97 compared to check variety Bouna Kalanamak was 2.50 .

Pusa 1652-10-11-2-1-1-1 and Pusa 07-62-3-13 can be used as commercial cultivars in Maharajganj and
\end{abstract} other Tarai district of Eastern Uttar Pradesh area after multi- location yield test trials.

Keywords: Rice, scented Rices, Kalanamak, evaluation, yield, domestic market

\section{Introduction}

More than $90 \%$ of the world's rice is grown and consumed in Asia, where $60 \%$ of the calories are consumed by 3 billion Asians (Khush, 1997) ${ }^{[7,8]}$. World per capita consumption is placed around the $56.9 \mathrm{~kg}$ (FAO, 2013) ${ }^{[2]}$. India is one of the world's largest producers of white rice, accounting for $20 \%$ of all world rice production. Aromatic rice, which has stronger aroma and kernel elongation than ordinary rice, has more in demand in different countries of the world. India is one of the largest exporter of basmati rice in world (Husaini et al., 2009) ${ }^{[5]}$. The consumer demand has increased markedly to pay a premium price for fragrance (Louis et al., 2005) ${ }^{[9]}$. Scented rices grow best and produce finest quality grains under cool, humid conditions, which are common in Himalayan Tarai of U.P and Uttarakhand and foot hills of Vindhya Hills. Hence Himalayan Tarai of Uttar Pradesh (U.P) and Uttarakhand is probably the place of origin of aromatic rices (Khush, 2000) ${ }^{[7,8]}$. Among non-basmati aromatic rices, Kalanamak is the most popular scented rice variety grown in Uttar Pradesh. It is among one of the most important scented rice varieties of India. This variety is famous for its taste and aroma. It is cooking at marriages is considered auspicious and it's smoke is believed to be 
purifying the atmosphere. It derives its name from its black husk. It is grown widely in Tarai area of Uttar Pradesh adjoining Nepal particularly in the districts of Siddharthnagar, Santkabirnagar and Basti and in small pockets in districts Gorakhpur, Maharajganj, Balrampur, Gonda, Bahraich, Shrawasti, Deoria and Padrauna (North Eastern Plain Zone of eastern UP). According to (H.N. Singh et al., 2006) ${ }^{[4,10]}$ there is no official record, but extensive discussion with farmers of its native area of cultivation revealed that Kalanamak used to be the most popular variety in this area until the 1970s. Rice is one cereal that is consumed mainly as whole milled and as boiled grain. The desired properties may vary from one ethnic group or geographical region to another and may vary from country to country (Juliano et al., 1964) ${ }^{[6]}$. The farmers started fast replacing Kalanamak, particularly because of its low and unstable yields. The critical production environment (favorable rain fed lowland) that was well suited to Kalanamak also provided an ideal situation for the Mahsuri group of rice varieties. Because of yield advantages, the inclusion of these varieties on farms enhanced farmers' gross income. Thus the area under these varieties increased and Kalanamak decreased. The area income relationship became negative for Kalanamak, while it was the reverse for Mahsuri (Singh H.N. et al. 2005) ${ }^{[4,10]}$. In farmers' fields, productivity ranged between 1.2 to $1.7 \mathrm{t} / \mathrm{ha}$. In the absence of any systematic breeding program and disorganized seed production (100\% farmers use their own saved seed), the level of admixtures greatly increased, thus adversely affecting its quality. Little attempt has been made in the past to improve Kalanamak with respect to quality and/or yield. A forum such as the Indigenous Aromatic Rice Export Development \& Promotion Foundation needs to be established. Today such a forum exists only for Basmati viz. the Basmati Export Development Foundation, which largely functions in cohesion with APEDA and inputs from traders. The role of farmers and scientists in such a foundation needs to be significantly increased.

The main objectives of the present study were, to evaluate Kalanamak rice line/varieties for yield and yield related traits and study the phenotypic and genotypic correlations among various yield related traits was on station and farmers fields.

\section{Materials and Methods}

The present study was carried out by Krishi Vigyan Kendra Basuli, Maharajganj, Achrya Narendra Dev University of Agriculture and Technology, Kumarganj, Ayodhya for two consecutive years from 2018-19 and 2019-20. The experiments laid out of two set $1^{\text {st }}$ was on station and $2^{\text {nd }}$ on farmers field of Maharajganj district with two block and two villages viz: block Siswa Bazar (Gopala \& Keshvari), Meethura (Karuta \& Parsauni). To evaluate the $7+2$ Kalanamak rice line/varieties. The nursery was sown $3^{\text {nd }}$ week of June every year. After 25 days, seedlings transplanted in the main field in Randomized Complete Block Design (RCBD) in three replications with a spacing of $20 \times 15 \mathrm{~cm}$. Recommended dose of fertilizer 60:40:40:15 kg N: P: K: and ZnSo4/ha Half of the dose of $\mathrm{N}$ and full dose of P: $\mathrm{K}$ and $\mathrm{ZnSo} 4$ were applied basal, while remaining $\mathrm{N}$ were topdressed in 2 equal splits-at tillering and panicle initiation stage. To control weeds, nomini gold @ 0.25 litre/ha was applied after 25 days old transplanting. Crop was harvested at physiological maturity and grain yield was calculated at $14 \%$ grain moisture. Single plant observations were recorded on five plants selected at random per genotype per replication for characters viz., plant height $\mathrm{cm}$, panicle per sqm, no. of spikelet's/panicle, SRF\% grain yield $\mathrm{kg} / \mathrm{ha}$, grain type and insect/pest and disease. The data on grain yield of each plot were recorded separately by threshing the harvested rice genotypes. The data so obtain were subjected to statistical analysis after necessary transformation for final statistical analysis (Gomez and Gomez, 1983) ${ }^{[3]}$. Two season data on grain yield separately recorded the mean value.

The data on seed yield, cost of cultivation and gross and net monetary return were collected from technological demonstration plot. In addition to this, data on farmer practices were also collected from the equal area. The benefit cost $(\mathrm{B}: \mathrm{C})$ ratio was calculated based on gross return. The following formulae were used to calculate the parameters as suggested by (Das et al. 1998) ${ }^{[1]}$ :

1. Increase in grain Yield = Grain yield from Kalanamak line/variety - Grain yield from check variety plot /Grain yield from Kalanamak line/variety X 100

2. Net Return $=$ Gross Return - Cost of cultivation

3. Benefit/Cost Ratio = Gross Return/Cost of Cultivation $\mathrm{X}$ 100

\section{Results and Discussion \\ Yield and attributing traits On station}

Highly significant varietal differences were observed for days to $50 \%$ flowering in the varieties tested (Table $1 \& 1 \mathrm{a}$ ). The days to $50 \%$ flowering ranged from 111 days Pusa 16520759-2-29-1-2, Pusa 1652-10-11-2-2-2-3 and Bouna Kalanamak to 121 days for Kalanamak (Treditional) variety.

\section{Farmers field}

The days to $50 \%$ flowering ranged from 109 days Pusa 16520759-2-29-1-2 to 121 days for Kalanamak (Treditional) variety.

Significant varietal differences were observed for number of panicle per sqm in the varieties tested (Table 1). The reason of difference in number of effective tiller per sqm is the variation in the genetic makeup of the variety. Among the various yield components productive tillers are very important as the final yield is mainly a function of the number of panicles bearing tillers per unit area (Roy et al. 2014). In the result of this study, Pusa 1638-07-5-3 line produced the highest number of panicle of on station \& farmers field $(272 / \mathrm{m} 2) \&$ farmers field Pusa 1638-07-5-3 (274/m2) followed by Pusa 1652-10-11-2$1-1-1$ of on station and farmers field $(257 \mathrm{~m} 2 \& 255 \mathrm{~m} 2)$. The lowest number of panicle per sqm (152 \& 169) was recorded for Kalanamak (Treditional) which was significantly lower than 272 and 274. (Table $1 \& 1$ a).

The rice varieties exhibited highly significant differences on grain yield as shown in Table $2 \& 2$ (a) and Figure 1 . The genotypes of Pusa 1652-10-11-2-1-1-1 on station and farmers field grain yield of $(3134 \mathrm{~kg} / \mathrm{ha} \& 3096 \mathrm{~kg} / \mathrm{ha})$, \% increase over check Bouna Kalanamak on station and farmers field $18.4 \% \& 19.39 \%$, followed by Pusa 07-62-3-13 grain yield of on station and farmers field ( $3059 \mathrm{~kg} / \mathrm{ha} \& 3088 \mathrm{~kg} / \mathrm{ha})$, grain yield increase over check was on station and farmers field $15.21 \%$ and $18.78 \%$ have high yield stability presented in Figure 2.

\section{Economics}

Different line/variety of Kalanamak were considered in economic analysis of farmers field demonstrations. The inputs and outputs price of commodities prevailed during the farmers field, were taken for calculating cost of cultivation, net returns and B:C ratio. (Table 3 and Figure 3). The investment on production by adopting improved Kalanamak line/varieties with a value of Rs. 32192/ha. Cultivation of under improved Kalanamak line/varities Pusa 1652-10-11-2-1-1-1fetch higher net return of value Rs. 95,976/- compared to check variety Bouna Kalanamak to amount of Rs. 80,383/- ha, followed by Pusa 07-62-3-13 Rs. 95,480/-, Pusa 1638-07-130-2-67-1-1-1 Rs. 92,504/- and Pusa 1652-10-11-2-2-2-3 of Rs. 90,613/-. The B:C ratio of improved Kalanamak lines/varieties of Pusa 
1652-10-11-2-1-1-1was 2.98, followed by Pusa 07-62-3-13 was 2.97 compared to check variety Bouna Kalanamak was 2.50. The results indicated significant differences among rice varieties for plant Height, number of panicle/m2 and grain yield. The highest grain yield was obtained from the Pusa 1652-10-11-2-1-1-1 and Pusa 07-62-3-13.

Table 1: Relationship between growth traits of kalanamak line/varieties (On station)

\begin{tabular}{|c|c|c|c|c|c|c|c|c|c|c|c|c|c|c|c|c|}
\hline \multirow[t]{2}{*}{ S. No. } & \multirow[t]{2}{*}{ Strains/Varieties } & \multicolumn{3}{|c|}{ Days to $50 \%$ flowering } & \multicolumn{3}{|c|}{$\begin{array}{c}\text { Days to days to } \\
\text { maturity }\end{array}$} & \multicolumn{3}{|c|}{ Plant height $\mathrm{cm}$} & \multicolumn{3}{|c|}{ Panicle/m2 } & \multicolumn{3}{|c|}{$\begin{array}{c}\text { No. of } \\
\text { spiklets/panicle }\end{array}$} \\
\hline & & 2018 & 2019 & Mean & 2018 & 2019 & Mean & 2018 & 2019 & Mean & 2018 & 2019 & Mean & 2018 & 2019 & Mean \\
\hline 1 & $\begin{array}{l}\text { Pusa 1652-0759-2-29-1-2 } \\
\text { 1659- }\end{array}$ & 110 & 112 & 111 & 138 & 141 & 140 & 126 & 120 & 123 & 226 & 230 & 228 & 334 & 341 & 338 \\
\hline 2 & & & & & 138 & 142 & 140 & 113 & 117 & 115 & 268 & 272 & 270 & 271 & 289 & 280 \\
\hline 3 & Pusa 163 & & & & 141 & & 143 & 107 & 109 & 108 & 205 & 209 & 207 & 289 & 303 & 296 \\
\hline 4 & $1-1-1$ & & & & 140 & 14 & 142 & 97 & 101 & 99 & 254 & 260 & 257 & 211 & 217 & 214 \\
\hline 5 & $2-2-3$ & & & & 140 & 139 & 140 & 2 & 94 & 93 & 240 & 243 & 242 & 241 & 249 & 245 \\
\hline 6 & & & & & 142 & 145 & 144 & 100 & 103 & 102 & 247 & 256 & 252 & 213 & 219 & 216 \\
\hline 7 & $2-10$ & & & & 140 & 143 & 142 & 97 & 93 & 95 & 254 & 241 & 248 & 289 & 292 & 291 \\
\hline 8 & & & & & 148 & 15 & 149 & 148 & 152 & 150 & 147 & 156 & 152 & 237 & 241 & 239 \\
\hline 9 & Bauna Kalanamak (Check) & 110 & 112 & 111 & 138 & 141 & 140 & 105 & 107 & 106 & 186 & 192 & 189 & 115 & 126 & 121 \\
\hline
\end{tabular}

Table 1(a): Relationship between growth traits of kalanamak line/varieties (Farmers field)

\begin{tabular}{|c|c|c|c|c|c|c|c|c|c|c|c|c|c|c|c|c|c|c|c|}
\hline \multirow{2}{*}{ S. No. } & \multirow{2}{*}{ Strains/Varieties } & \multicolumn{6}{|c|}{ Days to $50 \%$ flowering } & \multicolumn{6}{|c|}{ Plant height cm } & \multicolumn{6}{|c|}{ Panicle $/ \mathrm{m} 2$} \\
\hline & & F1 & F2 & F3 & F4 & F5 & Mean & F1 & F2 & F3 & $\mathbf{F 4}$ & F5 & Mean & F1 & F2 & F3 & F4 & F5 & Mean \\
\hline 1 & Pusa 1652-0 & 108 & 113 & 109 & 106 & 111 & 109 & 130 & 135 & 120 & 119 & 126 & 126 & 236 & 230 & 222 & 227 & 224 & 228 \\
\hline 2 & & 12 & 111 & 109 & 106 & 111 & & 109 & 103 & 111 & 120 & 116 & & 271 & 273 & 267 & 275 & 284 & 274 \\
\hline 3 & 1 & 14 & 116 & 115 & 113 & 116 & & 103 & 107 & 109 & 111 & 105 & & 203 & 207 & 211 & 204 & 201 & 205 \\
\hline 4 & & 11 & 113 & 115 & 109 & 110 & 112 & 103 & 105 & 107 & 101 & 103 & 104 & 260 & 251 & 256 & 260 & 249 & 255 \\
\hline 5 & & 113 & 114 & 118 & 112 & 115 & 114 & 95 & 97 & 101 & 93 & 92 & 96 & 239 & 234 & 241 & 249 & 243 & 241 \\
\hline 6 & & 117 & 118 & 120 & 116 & 115 & 117 & 105 & 109 & 103 & 101 & 104 & 104 & 252 & 259 & 263 & 241 & 249 & 253 \\
\hline 7 & & 113 & 117 & 109 & 115 & 112 & 113 & 93 & 90 & 96 & 102 & 105 & 97 & 241 & 239 & 249 & 256 & 249 & 247 \\
\hline 8 & 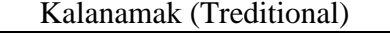 & 121 & 123 & 119 & 121 & 122 & 121 & 156 & 149 & 143 & 156 & 159 & 153 & 149 & 163 & 171 & 179 & 183 & 169 \\
\hline 9 & Bauna Kalanamak (Check) & 109 & 112 & 115 & 113 & 111 & 112 & 101 & 105 & 109 & 111 & 107 & 107 & 192 & 199 & 201 & 205 & 207 & 201 \\
\hline
\end{tabular}

Table 2: Relationship between yields and disease of kalanamak line/varieties (On station)

\begin{tabular}{|c|c|c|c|c|c|c|c|c|c|c|c|c|}
\hline \multirow{2}{*}{ S. No. } & \multirow{2}{*}{ Strains/Varieties } & \multicolumn{3}{|c|}{ SPF \% } & \multicolumn{3}{|c|}{ Grain yield kg/ha } & \multirow{2}{*}{$\begin{array}{c}\text { \% Increase over check bauna } \\
\text { kalanamak }\end{array}$} & \multirow{2}{*}{$\begin{array}{c}\text { Grain } \\
\text { Type }\end{array}$} & \multicolumn{3}{|c|}{ Disease } \\
\hline & & 2018 & 2019 & Mean & 2018 & 2019 & Mean & & & FS & BS & BLB \\
\hline 1 & Pusa 1652-0759-2-29-1-2 & 85 & 90 & 88 & 2700 & 2950 & 2825 & 6.40 & SS & 3 & 0 & 0 \\
\hline 2 & Pusa 1638-07-5-3 & 95 & 97 & 96 & 2750 & 2860 & 2805 & 5.34 & MB & 2 & 0 & 0 \\
\hline 3 & Pusa 1638-07-130-2-67-1-1-1 & 90 & 92 & 91 & 2900 & 3010 & 2955 & 11.29 & SS & 3 & 2 & 2 \\
\hline 4 & Pusa 1652-10-11-2-1-1-1 & 90 & 93 & 92 & 3100 & 3167 & 3134 & 18.04 & $\mathrm{MB}$ & 5 & 2 & 2 \\
\hline 5 & Pusa 1652-10-11-2-2-2-3 & 90 & 94 & 92 & 2900 & 3011 & 2956 & 11.33 & MS & 2 & 0 & 0 \\
\hline 6 & Pusa 07-62-3-13 & 95 & 98 & 97 & 2950 & 3167 & 3059 & 15.21 & MS & 5 & 0 & 0 \\
\hline 7 & Pusa 1638-07-62-2-10 & 85 & 89 & 87 & 2700 & 2711 & 2706 & 1.92 & SS & 2 & 1 & 1 \\
\hline 8 & Kalanamak (Treditional) & 90 & 93 & 92 & 2300 & 2410 & 2355 & -11.29 & SB & 3 & 0 & 0 \\
\hline 9 & Bauna Kalanamak (Check) & 95 & 95 & 95 & 2600 & 2710 & 2655 & - & SS & 2 & 0 & 1 \\
\hline
\end{tabular}

Table 2(a): Relationship between yields and disease of kalanamak line/varieties (Farmers fields)

\begin{tabular}{|c|c|c|c|c|c|c|c|c|c|c|c|c|c|c|c|c|c|c|}
\hline \multirow{2}{*}{\begin{tabular}{|l|} 
S. \\
No.
\end{tabular}} & \multirow{2}{*}{ Strains/Varieties } & \multicolumn{4}{|c|}{ No. of Spiklets/panicle } & \multicolumn{6}{|c|}{ SPF \% } & \multicolumn{6}{|c|}{ Grain yield kg/ha } & \multirow{2}{*}{$\begin{array}{c}\text { \% Increase over } \\
\text { check }\end{array}$} \\
\hline & & F1 & F2 & F3 & \begin{tabular}{|l|l|l|} 
F4 & F5 & Mean \\
\end{tabular} & F1 & F2 & F3 & F4 & F5 & Mean & F1 & F2 & F3 & F4 & F5 & Mean & \\
\hline 1 & 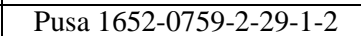 & 336 & 340 & 323 & \begin{tabular}{|l|l|}
337340 & 335 \\
\end{tabular} & 97 & 93 & 81 & 90 & 85 & 89 & 2800 & 2650 & 2763 & 2659 & 2783 & 2731 & 5.32 \\
\hline 2 & $8-07-5-3$ & 267 & 275 & 281 & 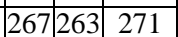 & 97 & 89 & 92 & 86 & 81 & 89 & 2810 & 2659 & 2550 & 2690 & 2750 & 2692 & 81 \\
\hline 3 & Pusa 1638-07-130-2-67-1-1-1 & 291 & 303 & 274 & \begin{tabular}{|l|l|}
276267 & 282 \\
\end{tabular} & 92 & 95 & 87 & 81 & 83 & 88 & 2950 & 3010 & 2860 & 2910 & 3190 & 2984 & 07 \\
\hline 4 & Pusa 1652-10-11-2-1-1-1 & 209 & 215 & 213 & \begin{tabular}{|l|l|}
207212 & 211 \\
\end{tabular} & 92 & 95 & 97 & 81 & 83 & 90 & 2910 & 3150 & 3060 & 3150 & 3210 & 3096 & 19.39 \\
\hline 5 & Pusa $1652-10-11-2-2-2-3$ & 243 & 236 & 231 & 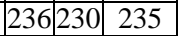 & 91 & 93 & 87 & 95 & 96 & 92 & 2950 & 2800 & 2967 & 2750 & 3150 & 2923 & 12.72 \\
\hline 6 & Pusa 07-62-3-13 & 209 & 213 & 211 & \begin{tabular}{|l|l|}
2152220 & 214 \\
\end{tabular} & 97 & 98 & 91 & 93 & 95 & 95 & 3010 & 3150 & 3090 & 2960 & 3190 & 3080 & 18.78 \\
\hline 7 & & 279 & 287 & 295 & \begin{tabular}{|l|l|l}
4 & 283
\end{tabular} & 86 & 87 & 91 & 85 & 84 & 87 & 2600 & 2750 & 2800 & 2500 & 2667 & 2663 & \\
\hline 8 & & 232 & 236 & 223 & \begin{tabular}{|l|l|l|}
231 & 229 & 230 \\
\end{tabular} & 91 & 87 & 85 & 92 & 93 & 90 & 2410 & 2015 & 2290 & 2310 & 2440 & 2293 & -11.56 \\
\hline 9 & Bauna Kalanamak (Check) & 119 & 117 & 121 & 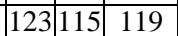 & 96 & 95 & 92 & 94 & 95 & 94 & 2700 & 2500 & 2400 & 2750 & 2615 & 2593 & - \\
\hline
\end{tabular}

Table 3: Economics of different kalanamak rice line/varieties of farmers field

\begin{tabular}{|c|c|c|c|c|c|c|}
\hline S. No. & Strains/Varieties & Cost of cash input & Sale price (Rs./q) & Grain yield (q/ha) & Total returns Rs. (ha & $\begin{array}{c}\text { Incremental benefit: } \\
\text { Cost ratio }\end{array}$ \\
\hline 1 & Pusa 1652-0759-2-29-1-2 & 32192 & 3100 & 27.31 & 84661 & 2.63 \\
\hline 2 & Pusa 1638-07-5-3 & 32192 & 3100 & 26.92 & 83452 & 2.59 \\
\hline 3 & Pusa 1638-07-130-2-67-1-1-1 & 32192 & 3100 & 29.84 & 92504 & 2.87 \\
\hline 4 & Pusa 1652-10-11-2-1-1-1 & 32192 & 3100 & 30.96 & 95976 & 2.98 \\
\hline 5 & Pusa 1652-10-11-2-2-2-3 & 32192 & 3100 & 29.23 & 90613 & \\
\hline 6 & Pusa 07-62-3-13 & 32192 & 3100 & 30.8 & 95480 & 2.81 \\
\hline 7 & Pusa 1638-07-62-2-10 & 32192 & 3100 & 26.63 & 82553 & 2.97 \\
\hline 8 & Kalanamak (Treditional) & 32192 & 3100 & 22.93 & 71083 & 2.56 \\
\hline 9 & Bauna Kalanamak (Check) & 32192 & 3100 & 25.93 & 80383 & 2.21 \\
\hline
\end{tabular}




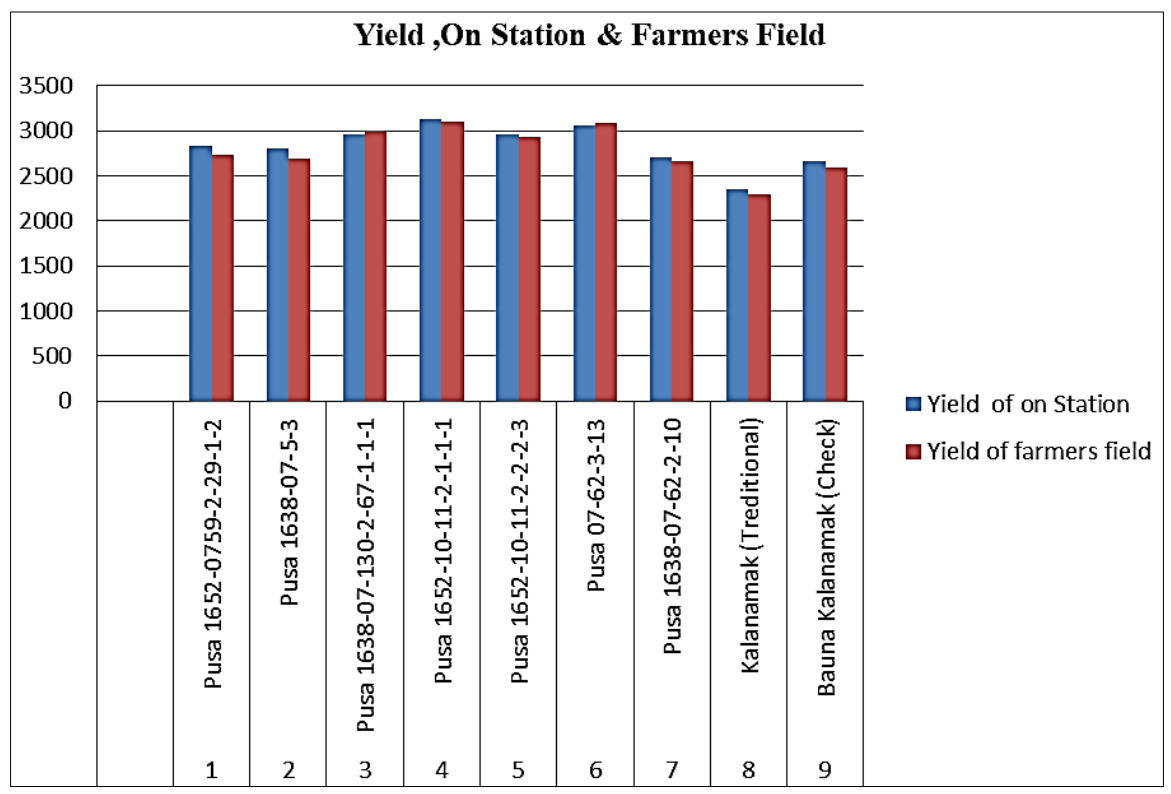

Fig 1: Grain yield of kalanamak rice line/varieties, on station and farmers field

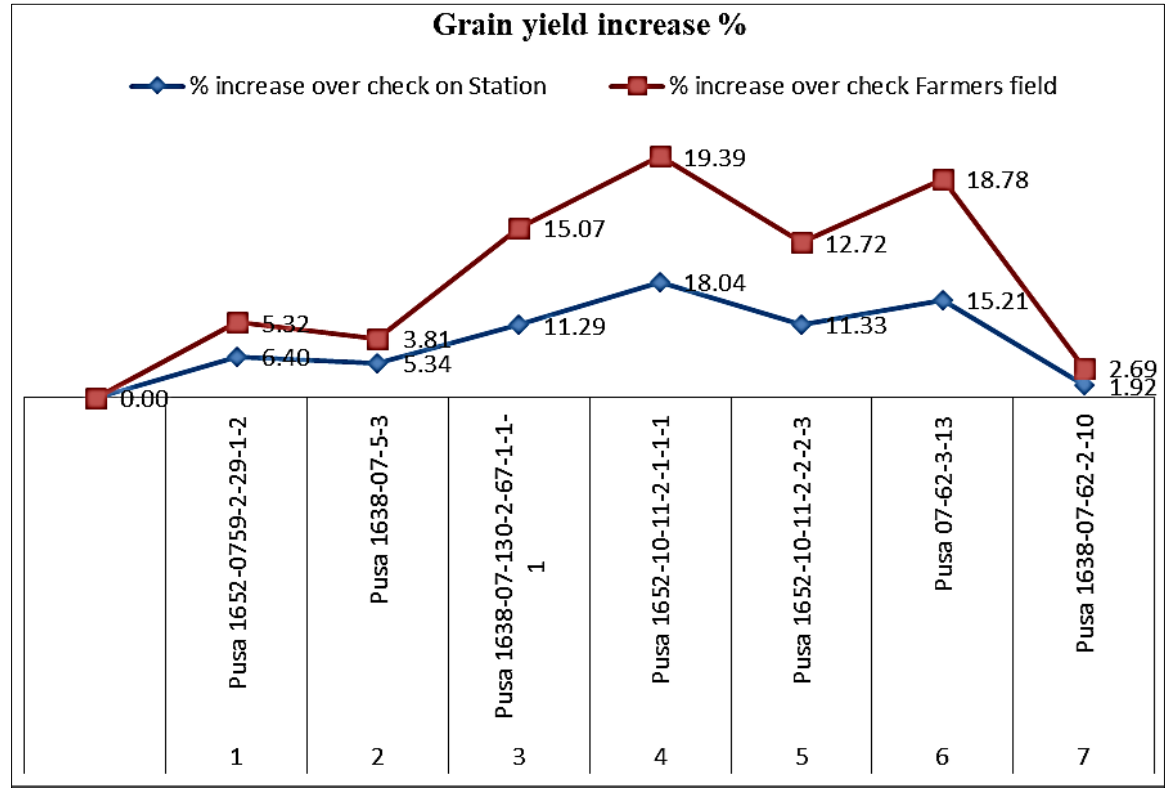

Fig 2: Grain yield increase over check

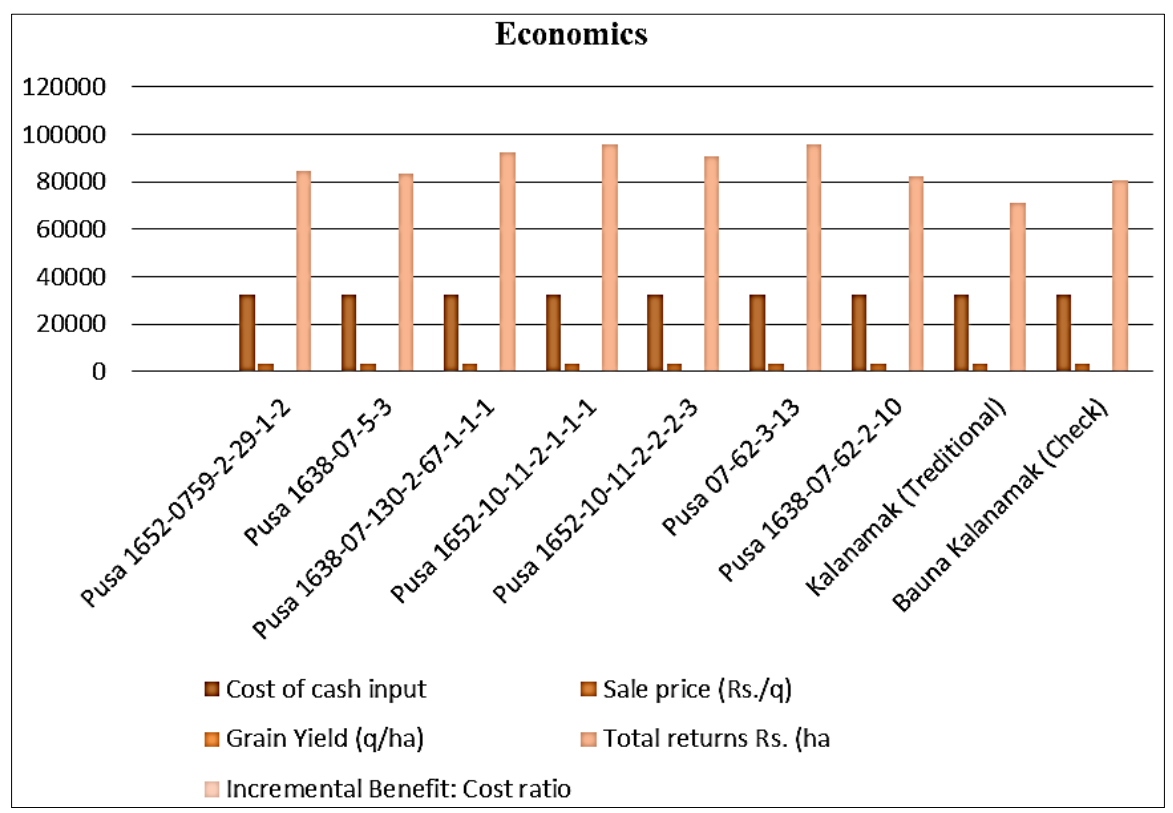

Fig 3: Economics of kalanamak rice line/varieties 


\section{References}

1. Das P, Das SK, Mishra PK, Mishra A, Tripathi AK. Farming system analysis of results of front line demonstration in pulse crops conducted in different agroclimatic Zone of Madhya Pradesh and Odissa ZCU for TOT Project Zone VII, Jabalpur 1998, P37.

2. FAO. United Nations statistical database. FAOSTAT, ITA. Akinbile, C.O. 2013. Assessment of the CERESRice model for rice production in Ibadan, Nigeria. Agric. Eng. Int. CIGR J 2013;15:19-26.

3. Gomez. Kwanchai Gomez. A. Statistical procedures for agricultural research with emphasis on rice. III. Title. \$540. \$7G65 1983 630' 2013;72:83-14556.

4. Singh HN, Singh US, Singh SP, Singh RK. Evaluation of Improved Kalanamak Rice Technology: Accelerating adoption and stabilizing productivity in Eastern Uttar Pradesh. International Journal of Rural Studies 2006;13 (01):01-06.

5. Husaini AM, Parray GA, Rather AG, Sanghera GS. Performance of elite basmati rice varieties of sub tropical India under temperate valley conditions of Kashmir, Genetic Resources. International Rice Research Notes 2009, P0117-185.

6. Juliano BO, Bautista GM, Lugay JC, Reyes AC. Studies on the physicochemical properties of rice. J Agric. Food Chem 1964;12:131-138.

7. Khush GS. Origin, dispersal, cultivation and variation of rice. Plant Mol. Biol 1997;35:25-34.

8. Khush GS. Taxonomy and origin of rice. In: Aromatic Rices (Singh RK, Singh US, and Khush GS, Eds.). Oxford \& IBH Publishing Co., New Delhi 2000, P5-14.

9. Louis MTB, Robert JH, Quinsheng J, Russell FR, Daniel LEW. A perfect marker for fragrance genotyping in rice. Mol. Breeding 2005;16:279-283.

10. Singh HN, Singh S, Singh US, Singh A, Singh RK, Mani SC. Kalanamak rice research: Breaking the yield barriers and improving equity. In: Scented rices of Uttar Pradesh and Uttaranchal (Singh RK and Singh US) Kalyani Publishers New Delhi 2005, P114-128.

11. Warde PN, Bhope RS, Chudhary DP. Adoption of dry land horticulture technology. Maharastra J Extn Edu 1991;10(2):108-111. 